\title{
Cyclic Voltammetric behaviour of Dimensionally Stable Anodes in the Presence of C1 - C3 Aldehydes
}

\author{
Geoffroy R. P. Malpass and Artur J. Motheo*
}

Instituto de Química de São Carlos, Universidade de São Paulo, CP 780, 13560-970 São Carlos - SP, Brazil

\begin{abstract}
Este trabalho descreve o estudo voltamétrico de três aldeídos alifáticos: formaldeído, acetaldeído e propionaldeído sobre ânodos do tipo Dimensionalmente Estáveis ( $\mathrm{ADE}^{\circledR}$ ). Eletrodos com composição $\mathrm{Ti} / \mathrm{Ru}_{0.3} \mathrm{M}_{0.7} \mathrm{O}_{2}$ (onde $\mathrm{M}=\mathrm{Ti}$ ou $\mathrm{Sn}$ ) foram utilizados em solução de $0.5 \mathrm{~mol} \mathrm{dm}{ }^{-3}$ $\mathrm{H}_{2} \mathrm{SO}_{4}$ usando uma célula do tipo filtro-prensa. Ambos os eletrodos apresentam um comportamento típico dos $\mathrm{ADE}^{\circledR}$ frente a oxidação de formaldeído. Porém, para acetaldeído e propionaldeído, um desvio do padrão é observado na forma de uma diminuição da carga anódica faradaica normalizada $\left(\mathrm{q}_{\mathrm{fn}}\right)$ e da densidade da corrente associada com a reação de desprendimento de oxigênio (RDO). Um possível mecanismo considerando a oxidação direta dos aldeídos é sugerido.
\end{abstract}

This work describes the cyclic voltammetry study of three aliphatic aldehydes: formaldehyde, acetaldehyde and propionaldehyde at dimensionally stable anodes (DSA $\left.{ }^{\circledR}\right)$. Electrodes of nominal composition $\mathrm{Ti} / \mathrm{Ru}_{0.3} \mathrm{M}_{0.7} \mathrm{O}_{2}$ (where $\mathrm{M}=\mathrm{Ti}$ ou $\mathrm{Sn}$ ) were used in $0.5 \mathrm{~mol} \mathrm{dm}{ }^{-3} \mathrm{H}_{2} \mathrm{SO}_{4}$ in a filter-press cell. Both electrodes exhibit behaviour typical of such materials in the presence of formaldehyde. However, with acetaldehyde and propionaldehyde non-typical behaviour is observed. This is characterised by a fall in the normalised faradaic anodic charge $\left(\mathrm{q}_{\mathrm{nf}}\right)$ and also a decrease in the current density associated with the oxygen evolution reaction (OER). A possible reaction mechanism, considering the direct oxidation of the aldehyde at the electrode surface, is suggested.

Keywords: formaldehyde, acetaldehyde, propionaldehyde, electrooxidation, DSA ${ }^{\circledR}$

\section{Introduction}

The presently accepted model for organic oxidation at $\mathrm{DSA}^{\circledR}$ electrodes is that proposed by Comninellis and De Battisti, ${ }^{1}$ which considers that oxidation takes place under conditions of simultaneous oxygen evolution. The nature of the electrode material is known to affect the mechanism of oxidation, ${ }^{1}$ where so called "active" electrodes mediate the oxidation of an organic species via the formation of higher oxides of the metal, $\left(\mathrm{MO}_{\mathrm{x}+1}\right)$, if a higher oxidation state is available (e.g. $\mathrm{RuO}_{2}$ or $\mathrm{IrO}_{2}$ ). This leads to selective oxidation. "Non-active" electrodes present no higher oxidation state available and the organic species is directly oxidised by an adsorbed hydroxyl radical - giving complete combustion (e.g. $\mathrm{SnO}_{2}$ or $\mathrm{PbO}_{2}$ ). Essentially, both processes require, as the initial step, the formation of $\left({ }^{\circ} \mathrm{OH}\right)_{\mathrm{ads}}$.

Apart from the nature of the electrode material, other factors, such as organic concentration ${ }^{2}$ and the type of organic species present ${ }^{3}$ are known to play an important

\footnotetext{
*e-mail: artur@iqsc.sc.usp.br
}

role in the oxidation process. However, few studies deal with the effect of concentration or, in fact, deal with high organic concentration.

Cyclic voltammograms of $\mathrm{DSA}^{\circledR}$ electrodes in acidic media generally display broad peaks between the oxygen evolution reaction (OER) and the hydrogen evolution reaction (HER), which correspond to oxidation state transitions (e.g. $\mathrm{Ru}(\mathrm{IV})$ to $\mathrm{Ru}(\mathrm{VI})$ ). In cyclic voltammetry the oxidation of an organic species at DSA ${ }^{\circledR}$ electrodes is classically manifested by a decrease of the overpotential current associated with the OER.

Previous investigations of the effect of aldehydes on the voltammetric behaviour of DSA electrodes are few, with the paper by O'Sullivan and White being one notable exception. ${ }^{4}$ The majority of the work has been done with the corresponding alcohols - methanol, ${ }^{5}$ ethanol, ${ }^{6,7}$ as examples. Burke and Murphy described the oxidation of methanol at $\mathrm{RuO}_{2}$ electrodes and suggested that oxidation occurred via interaction with an $\mathrm{OH}_{\text {ads }}$ species at the electrode surface. ${ }^{5}$ However, it was also noticed that at higher concentrations (in the absence of $\mathrm{H}_{2} \mathrm{O}$ ) that oxidation to formaldehyde also occurred. ${ }^{5}$ Zanta et al. ${ }^{8}$ 
described the solvent effect on the oxidation of isosafrol and concluded that, in the absence of protons, the suppurating electrolyte cation can participate in the solid state redox transitions.

The aliphatic aldehydes (formaldehyde, acetaldehyde and propionaldehyde) are highly reactive compounds, and are used in a wide number of industrial applications. Electrochemical studies of aldehydes by Sibille et al. ${ }^{9}$ on $\mathrm{Pt}$ and $\mathrm{Au}$ and Fleury et al. ${ }^{10}$ on $\mathrm{Hg}$ electrodes suggest that the electro-active species is the "gem-ol-olate" ion $\left(\mathrm{RC}(\mathrm{OH}) \mathrm{O}^{-}\right)$.

The present work reports the study by cyclic voltammetry of the effect of the concentration on the oxidation of formaldehyde, acetaldehyde and propionaldehyde at two DSA type electrodes.

\section{Experimental}

A two-compartment filter-press cell, separated by an ion exchange membrane (IONAC AM 3470), was used with a Ti/ $\mathrm{Ru}_{0.3} \mathrm{Ti}_{0.7} \mathrm{O}_{2} \mathrm{DSA}^{\circledR}$ anode (nominal area, $14 \mathrm{~cm}^{2}$ ) and a stainless steel plate cathode (area $14 \mathrm{~cm}^{2}$ ) as described elsewhere. . $^{2,3,11}$

The $\mathrm{Ti} / \mathrm{Ru}_{0.3} \mathrm{Sn}_{0.7} \mathrm{O}_{2}$ electrode was prepared in the laboratory by the standard technique of thermal decomposition of the appropriate mixture of precursor salts $\left(0.2 \mathrm{~mol} \mathrm{dm}^{-3} \mathrm{SnCl}_{2}\right.$ and $\mathrm{RuCl}_{3} \cdot \mathrm{nH}_{2} \mathrm{O}$ dissolved in $1: 1 \mathrm{HCl}$ $(\mathrm{v} / \mathrm{v}))$ at $400^{\circ} \mathrm{C}$ under a flux of oxygen $\left(5 \mathrm{~cm}^{3} \mathrm{~min}^{-1}\right)$. After each addition of chloride precursors the electrode was calcinated for ten min. When the desired mass was achieved the electrode was calcinated for a further hour. The $\mathrm{Ti} / \mathrm{Ru}_{0.3} \mathrm{Ti}_{0.7} \mathrm{O}_{2}$ electrode was obtained commercially from De Nora, Brazil.

The cyclic voltammetry measurements were carried out in in $0.5 \mathrm{~mol} \mathrm{dm}^{-3} \mathrm{H}_{2} \mathrm{SO}_{4}$ using a potentiostat (EG\&G/PAR model 273). The potentials in this study are referred to the $\mathrm{Hg} / \mathrm{Hg}_{2} \mathrm{SO}_{4} / \mathrm{SO}_{4}{ }^{2-}$ (MSE) reference electrode.

Acetaldehyde $\left(\mathrm{CH}_{3} \mathrm{CHO}>99 \%\right)$ and propionaldehyde $\left(\mathrm{CH}_{3} \mathrm{CH}_{2} \mathrm{CHO}>98 \%\right)$ were obtained from Merck and used without further purification. The other reagents formaldehyde $\left(\mathrm{H}_{2} \mathrm{CO}-37 \%\right.$ solution with $12.5 \%$ methanol), sulphuric acid $\left(\mathrm{H}_{2} \mathrm{SO}_{4}-98 \%\right)$, formic acid ( $\mathrm{HCOOH}-94.8 \%)$, were obtained from Mallinckrodt and also used without further purification.

\section{Results and Discussion}

In $0.5 \mathrm{~mol} \mathrm{dm}^{-3}$ all electrodes present typical $\mathrm{DSA}^{\circledR}$ features with a broad double layer region, before the onset of the oxygen evolution reaction (OER), where oxide transitions take place. The specific anodic charge $\left(\mathrm{q}_{\mathrm{a}} / \mathrm{mC}\right.$ $\mathrm{cm}^{-2}$ ) has the order of magnitude $\mathrm{Ti} / \mathrm{Ru}_{0.3} \mathrm{Sn}_{0.7} \mathrm{O}_{2}>$ $\mathrm{Ti} / \mathrm{Ru}_{0.3} \mathrm{Ti}_{0.7} \mathrm{O}_{2}$. The value of $\mathrm{q}_{\mathrm{a}}$ is considered a measure of the electro-active area of DSA electrodes ${ }^{12}$ and in this work was calculated in the region of water stability $(-0.2$ to $0.5 \mathrm{~V}$ vs. MSE, Figure 1). The determination of $\mathrm{q}_{\mathrm{fN}}$ was done by establishing the potential range in which oxidation of the organic takes place $(\mathrm{E}>0.5 \mathrm{~V} v s$. MSE at high organic concentrations). Thus, the charge was calculated from $0.5 \mathrm{~V}$ to $1.0 \mathrm{~V}$ in the absence of the organic species and denoted $\mathrm{q}_{\mathrm{SE}}$ (i.e. the charge due to the supporting electrolyte). In the presence of the organic species the charge was then calculated over the same potential range and denoted as $\mathrm{q}_{\mathrm{T}}$. The value of the faradaic charge, $\mathrm{q}_{\mathrm{f}}$, is determined by the term:

$\mathrm{q}_{\mathrm{f}}=\mathrm{q}_{\mathrm{T}}-\mathrm{q}_{\mathrm{SE}}$

Thus, the value of $\mathrm{q}_{\mathrm{f}}$ is a measure of the charge associated with the oxidation of the organic species. By dividing $\mathrm{q}_{\mathrm{f}}$ by the value of $\mathrm{q}_{\mathrm{a}}$ for a given electrode, it is possible to eliminate the morphological effects of the electrode. ${ }^{8}$ In this way it is possible to compare different electrode materials.

The effect of increasing the scan rate results in a fall in the value of $\mathrm{q}_{\mathrm{a}}$. This phenomenon has been observed before, and is attributed to the inaccessibility of the internal sites. $^{13}$

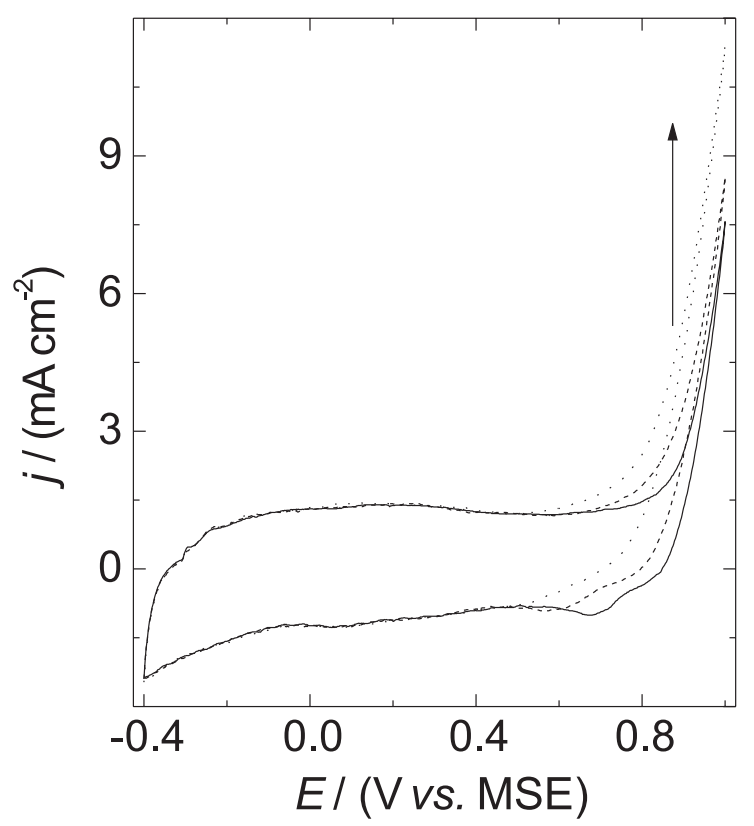

Figure 1. Cyclic voltammogram of $\mathrm{Ti} / \mathrm{Ru}_{0.3} \mathrm{Ti}_{0.7} \mathrm{O}_{2}$ in $0.5 \mathrm{~mol} \mathrm{dm}$ with (solid line) 0.0 , (dashed line) 0.1 and (dotted line) $0.2 \mathrm{mmol}$ $\mathrm{dm}^{-3} \mathrm{H}_{2} \mathrm{CO} . \mathrm{v}=20 \mathrm{mV} \mathrm{s}^{-1}$. Arrow indicates ancreasing current. 
In the presence of formaldehyde both electrodes exhibit typical DSA behaviour with a decrease in the overpotential of the onset of the current generally associated with the OER (Figure 1). Considering the currently accepted mechanism, ${ }^{1}$ this effect is the result of the simultaneous oxidation of the organic species and evolution of $\mathrm{O}_{2}$.

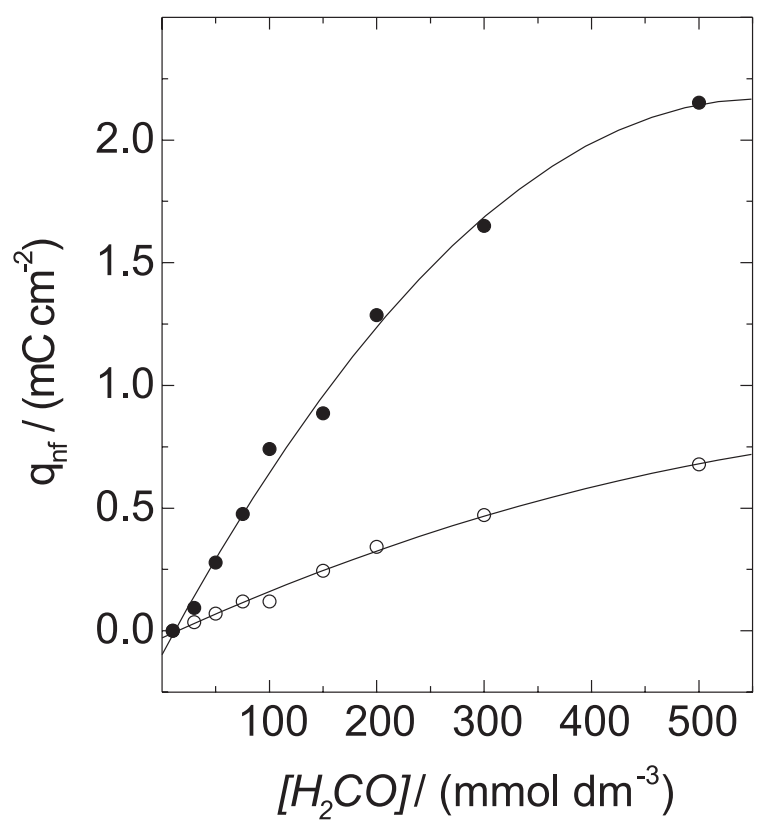

Figure 2. Variation of $\mathrm{q}_{\mathrm{nf}}$ with concentration: $(\mathrm{O}) \mathrm{Ti} / \mathrm{Ru}_{0.3} \mathrm{Ti}_{0.7} \mathrm{O}_{2}$ and (•) $\mathrm{Ti} / \mathrm{Ru}_{0.3} \mathrm{Sn}_{0.7} \mathrm{O}_{2}$.

The effect of increasing the concentration of formaldehyde is to cause an increase in the value of $\mathrm{q}_{\mathrm{nf}}$. This increase is initially linear, but at higher concentrations this tendency can be seen to tail off (Figure 2). From Figure 2 it can be observed that the rate of increase of $\mathrm{q}_{\mathrm{nf}}$ with formaldehyde concentration is much higher for the electrode $\mathrm{Ti} / \mathrm{Ru}_{0.3} \mathrm{Sn}_{0.7} \mathrm{O}_{2}$. This observation suggests that the catalytic activity of the $\mathrm{Ti} / \mathrm{Ru}_{0.3} \mathrm{Sn}_{0.7} \mathrm{O}_{2}$ anode towards the oxidation of formaldehyde is greater than that of the $\mathrm{Ti} / \mathrm{Ru}_{0.3} \mathrm{Ti}_{0.7} \mathrm{O}_{2}$ anode. The same can be seen when dealing with the oxidation of formic acid. The overpotential of the the $\operatorname{OER}\left(\eta_{\mathrm{OER}}\right)$, at a given current density, can be seen to decrease with increasing formaldehyde concentration for both electrodes (Figures 3 and 4). The current at which $\eta_{\text {OER }}$ was determined varied for each electrode due to the fact that each electrode presents different values of $q_{a}$ and $\eta_{\text {OER }}$. It was necessary to choose a value of $\mathrm{j}$ which was reached in all the voltammograms. In this way the value of $\eta_{\text {OER }}$ for the $\mathrm{Ti} / \mathrm{Ru}_{0.3} \mathrm{Ti}_{0.7} \mathrm{O}_{2}$ anode was $4 \mathrm{~mA} \mathrm{~cm} \mathrm{~cm}^{-2}$ whereas for the $\mathrm{Ti} / \mathrm{Ru}_{0.3} \mathrm{Sn}_{0.7} \mathrm{O}_{2}$ anode the value was $7.5 \mathrm{~mA} \mathrm{~cm}{ }^{-2}$. This was done in order to have a value where only the current associated with the OER is seen (see Figure 5) and no other processes are occur. As can be seen from Figures 3 and 4 , both the electrodes present an anticipation of the current associated with the OER of about $0.1 \mathrm{~V}$ over the concentration range used (or $\sim 0.2 \mathrm{mV} \mathrm{mmol}^{-1} \mathrm{dm}^{3}$ ).

The voltammetric response of the $\mathrm{Ti} / \mathrm{Ru}_{0.3} \mathrm{Ti}_{0.7} \mathrm{O}_{2}$ anode in solutions containing acetaldehyde is similar to that seen

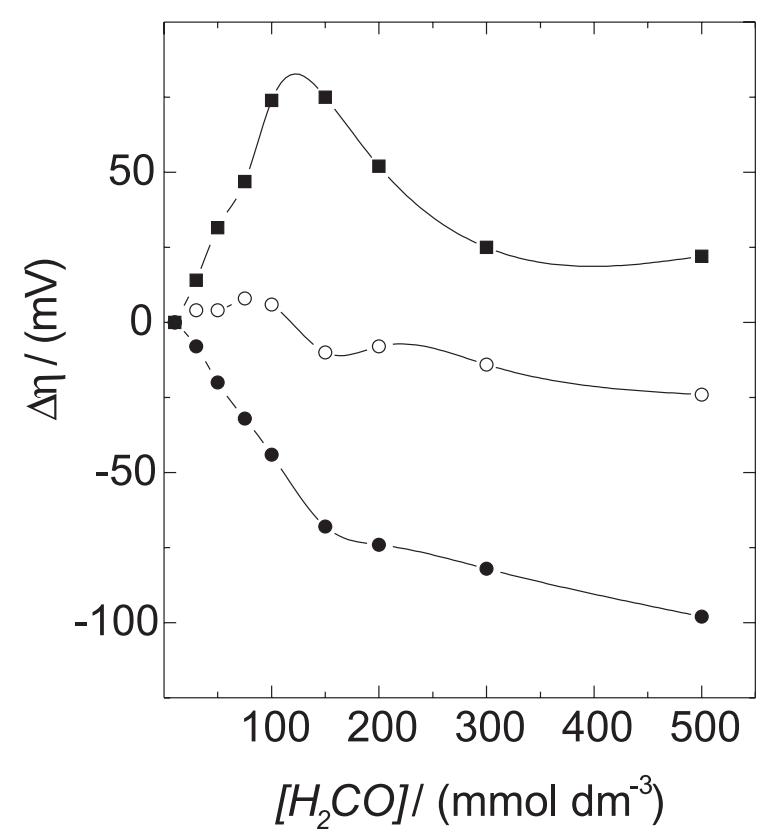

Figure 3. Variation of the overpotential of the $\operatorname{OER}\left(\eta_{\mathrm{OER}}\right)$ for the electrode $\mathrm{Ti} / \mathrm{Ru}_{0.3} \mathrm{Ti}_{0.7} \mathrm{O}_{2}$. (@) $\mathrm{HCHO},(\mathrm{O}) \mathrm{CH}_{3} \mathrm{CHO}$ and $\mathrm{CH}_{3} \mathrm{CH}_{2} \mathrm{CHO}$.

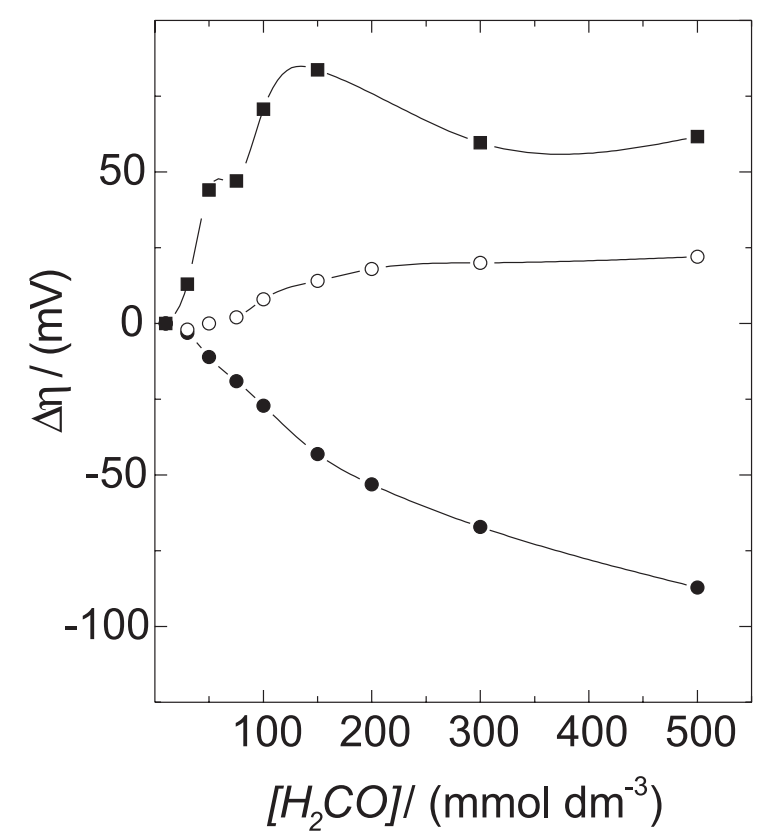

Figure 4. Variation of the overpotential of the OER $\left(\eta_{\mathrm{OER}}\right)$ for the electrode $\mathrm{Ti} / \mathrm{Ru}_{0.3} \mathrm{Sn}_{0.7} \mathrm{O}_{2}$. (@) $\mathrm{HCHO},(\mathrm{O}) \mathrm{CH}_{3} \mathrm{CHO}$ and (ם) $\mathrm{CH}_{3} \mathrm{CH}_{2} \mathrm{CHO}$. 
for formaldehyde, i.e. an increase in the value of $\mathrm{q}_{\mathrm{nf}}$ and decrease in the overpotential of the OER. On the other hand, the behaviour of the $\mathrm{Ti} / \mathrm{Ru}_{0.3} \mathrm{Sn}_{0.7} \mathrm{O}_{2}$ electrode diverges from that expected i.e. the current of the OER, between the potential limits used, decreases, and the value of $\mathrm{q}_{\mathrm{nf}}$ also falls with increase in the concentration (Figures 5 to 7). Figures 6 and 7 present the $\mathrm{q}_{\mathrm{nf}}$ values for both electrodes in solutions containing acetaldehyde and propionaldehyde, respectively. However, it is apparent that there is an increase in the current response in the area just prior to the OER $(0.6-0.8 \mathrm{~V}$ - pointed out in Figure 5) and this is probably due to adsorption of the aldehyde and/or its oxidation at the electrode surface.

The variation of the overpotential of the OER in the presence of acetaldehyde and propionaldehyde can be seen in Figure 3. It can been seen that the value of $\eta_{\mathrm{OER}}$ varies differently for each electrode, in agreement with the variation of $\mathrm{q}_{\mathrm{nf}}$. The $\mathrm{Ti} / \mathrm{Ru}_{0.3} \mathrm{Ti}_{0.7} \mathrm{O}_{2}$ anode shows a decrease in $\eta_{\text {OER }}$ whereas the $\mathrm{Ti} / \mathrm{Ru}_{0.3} \mathrm{Sn}_{0.7} \mathrm{O}_{2}$ anode shows an increase. For propionaldehyde both electrodes show an increase in the value of $\eta_{\text {OER }}$.

The authors feel that the decrease in the value of $q_{n f}$ is not due to the formation of a polymeric film on the electrode surface. This belief is based on the fact that the voltammograms recorded in the supporting electrolyte before and after each experiment were superimposable. It should also be noted that the value of $\mathrm{q}_{\mathrm{a}}$ considering the oxide transitions in the region -0.2 to $0.5 \mathrm{~V} v s$. MSE

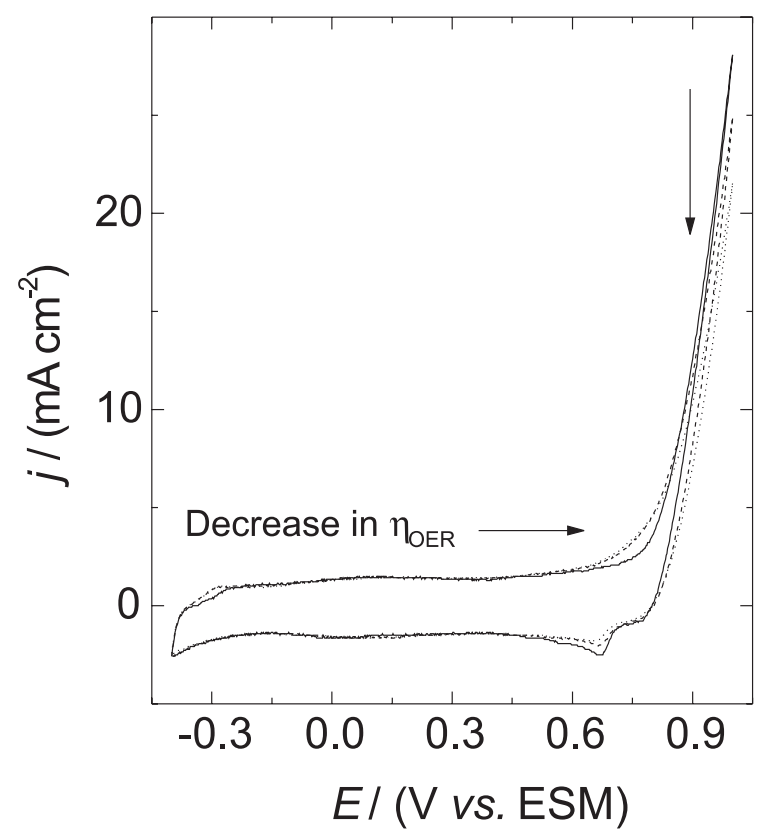

Figure 5. Cyclic voltammogram of $\mathrm{Ti} / \mathrm{Ru}_{03} \mathrm{Sn}_{07} \mathrm{O}_{2}$ in $0.5 \mathrm{~mol} \mathrm{dm}{ }^{-3}$ with (solid line) 0.0 , (dashed line) 0.1 and (dotted line) $0.2 \mathrm{mmol}$ $\mathrm{dm}^{-3} \mathrm{CH}_{3} \mathrm{CHO} . \mathrm{v}=20 \mathrm{mV} \mathrm{s}^{-1}$. Non labeled arrow indicates decreasing current.

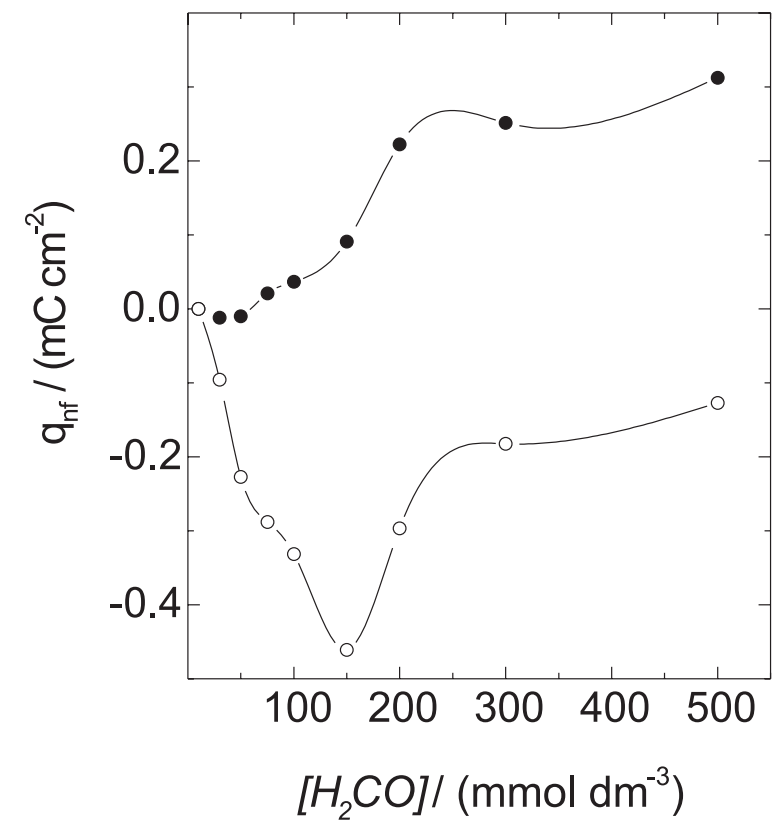

Figure 6. Variation of $\mathrm{q}_{\mathrm{nf}}$ with concentration for $\mathrm{Ti} / \mathrm{Ru}_{0.3} \mathrm{Ti}_{0.7} \mathrm{O}_{2}$. (m) $\mathrm{CH}_{3} \mathrm{CHO}$ and (l) $\mathrm{CH}_{3} \mathrm{CH}_{2} \mathrm{CHO}$.

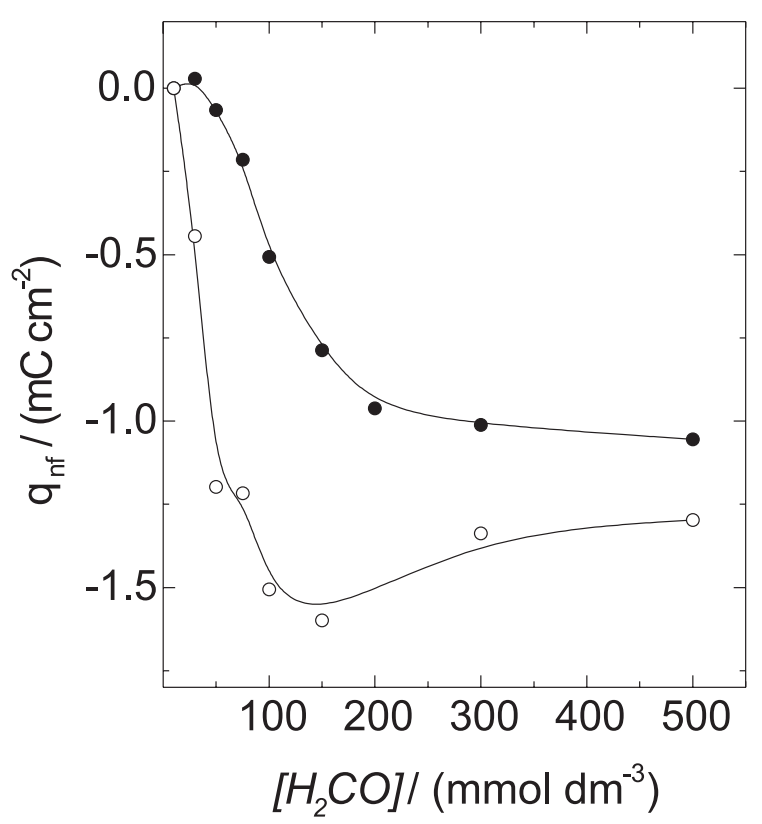

Figure 7. Variation of $\mathrm{q}_{\mathrm{nf}}$ with concentration for $\mathrm{Ti} / \mathrm{Ru}_{0.3} \mathrm{Sn}_{0.7} \mathrm{O}_{2}$. (m) $\mathrm{CH}_{3} \mathrm{CHO}$ and (1) $\mathrm{CH}_{3} \mathrm{CH}_{2} \mathrm{CHO}$.

remains unchanged in the presence of the organic (Figures $1,5$ and 8$)$.

In propionaldehyde both the electrodes studied exhibit the non-typical behaviour seen in acetaldehyde for the Ti/ $\mathrm{Ru}_{0.3} \mathrm{Sn}_{0.7} \mathrm{O}_{2}$ (Figure 8). A simple reason for this decrease would be that the increased concentration of aldehyde inhibits the formation of $\left({ }^{\circ} \mathrm{OH}\right)_{\text {ads }}$ and thus the production 


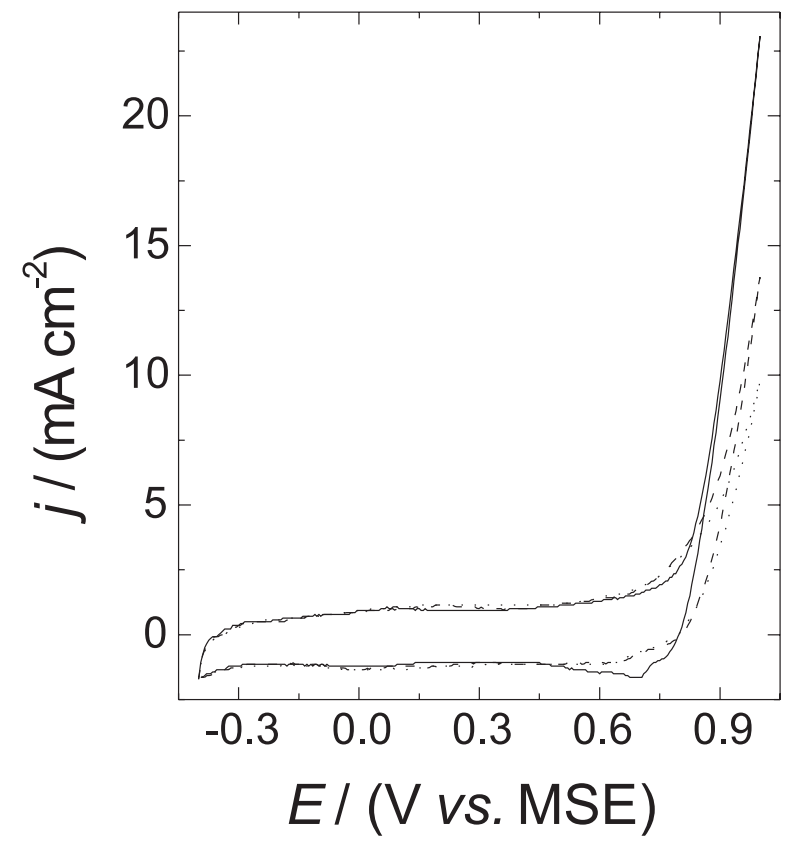

Figure 8. Cyclic voltammogram of $\mathrm{Ti} / \mathrm{Ru}_{03} \mathrm{Sn}_{07} \mathrm{O}_{2}$ in $0.5 \mathrm{~mol} \mathrm{dm}-3$ with (solid line) 0.0 , (dashed line) 0.1 and (dotted line) $0.2 \mathrm{mmol}$ $\mathrm{dm}^{-3} \mathrm{CH}_{3} \mathrm{CH}_{2} \mathrm{CHO}$. $\mathrm{v}=20 \mathrm{mV} \mathrm{s}^{-1}$.

of $\mathrm{O}_{2}$ (hence the current associated with the OER) decreases. Also, the consumption of $\left({ }^{\circ} \mathrm{OH}\right)_{\text {ads }}$ in the oxidation of the aldehyde would result in a decrease in the current associated with the OER. It is interesting to note that the values of $q_{n f}$ initially decrease with increasing concentration of propionaldehyde for both electrodes. However, after about $0.1 \mathrm{~mol} \mathrm{dm}^{-3}$ the value of $\mathrm{q}_{\mathrm{nf}}$ can be seen to increase slightly (Figures 6 and 7). This change is more marked for the electrode $\mathrm{Ti} / \mathrm{Ru}_{0.3} \mathrm{Ti}_{0.7} \mathrm{O}_{2}$.

\section{Overall discussion}

The observations made cannot simply explained by the inhibition/consumption of $\left({ }^{\circ} \mathrm{OH}\right)_{\text {ads }}$ as this should also occur at high concentrations of formaldehyde and formic acid, but does not. Ristic et al. ${ }^{14}$ observed the inhibition of the formation of superficial oxides on platinum in the presence of aldehydes. It was suggested that, with aldehydes present in sufficient quantities, competition between the "direct" anodic oxidation and formation of the superficial oxide (which leads to "indirect" oxidation) occurs. This is similar to the mechanism proposed by Fleury et al..$^{10}$ where the oxidation of the aldehyde is said to occur directly at the $\mathrm{Hg}$ (II) species. During the oxidation of methanol at $\mathrm{RuO}_{2}$ electrodes it was observed that, even when the electrolyte consisted purely of methanol, oxidation continued to take place. ${ }^{5}$ In this light it is clear that oxidation does not necessarily require the presence of $\left({ }^{\circ} \mathrm{OH}\right)_{\text {ads }}$ to occur at $\mathrm{RuO}_{2}$ electrodes and that other pathways are possible.

It needs to be stated that the aldehyde can exist in two different forms in aqueous solutions; in the form of the pure aldehyde and as a hydrate known as the "gem-diol" $\left(\mathrm{RC}(\mathrm{OH})_{2}\right) \cdot{ }^{14}$ Electrochemical studies of aldehydes by Sibille et al..$^{9}$ on $\mathrm{Pt}$ and $\mathrm{Au}$ and Fleury et al. ${ }^{10}$ on $\mathrm{Hg}$ electrodes suggest that the electro-active species is the "gem-ol-olate" ion $\left(\mathrm{RC}(\mathrm{OH}) \mathrm{O}^{-}\right)$in basic conditions. In this way it is most probable that the gem-diol or some specie of that kind is the reacting species. In this way it is possible that the direct reaction of the gem-diol at the surface of the electrode is the predominant reaction at high aldehyde concentrations. As the gem-diol already contains two oxygen atoms the absence of the $(\mathrm{OH})_{\text {ads }}$ sites responsible for oxidation according to the Comninellis and De Battisti ${ }^{1}$ mechanism is not necessary. Whether such an oxidation mechanism involves the sublimation of the $\mathrm{OH}$ present to form $\mathrm{OH}_{\text {ads }}$ or if there is a direct interaction of the gem-diol and an internal rearrangement is beyond the scope of this work. But clearly, the two-electron transfer required to reduce the $\mathrm{Ru}(\mathrm{VI})$ species could be supplied directly from the gem-diol. This can be represented in the generic form in scheme 1 :

$$
\mathrm{RC}(\mathrm{OH})_{2}+\mathrm{Ru}(\mathrm{VI}) \rightarrow \mathrm{Ru}(\mathrm{IV})+\mathrm{RCOOH}+\mathrm{H}^{+}
$$

Scheme 1.

Thus, as proposed by Burke and Murphy, ${ }^{5}$ an inner sphere oxidation route occurring at the metal cations at the dehydrated $\mathrm{RuO}_{2}$ sites is possible. Obviously, under the conditions employed it is probable that a mixture of the "classic" indirect and direct oxidation takes place. Such a reaction route would be a continuation of the "active" mechanism described by Comninellis e De Battisti. ${ }^{1}$

\section{Conclusions}

The cyclic voltammetry study of two DSA ${ }^{\oplus}$ electrodes of nominal composition $\mathrm{Ti} / \mathrm{Ru}_{0.3} \mathrm{M}_{0.7} \mathrm{O}_{2}$, in the presence of lower order aldehydes, has been presented. It has been shown that there is a deviation from the classic behaviour normally seen in the presence of organic substrates. A tentative mechanism is presented that considers the possible direct oxidation at the cations formed on the electrode. 


\section{Acknowledgments}

The authors wish to thank FAPESP (process $n^{\circ}$ 99/ 07599-6), Brazil, for the financial support. Thanks are given to Dr. P. Olivi and Dr. A. de Andrade (FFCLRP) for supplying the laboratory made electrode.

\section{References}

1. Comninellis, Ch.; De Battisti, A.; J. Chim. Phys. 1996, 93, 673.

2. Malpass G. R. P.; Motheo, A. J.; J. Appl. Electrochem. 2001, 31, 1351.

3. Malpass G. R. P.; Motheo, A. J.; J. Braz. Chem Soc. 2003, 14, 65.

4. O’Sullivan, E. J. M.; White, J. R.; J. Electrochem. Soc. 1989, 136, 2576.

5. Burke, L. D.; Murphy, J.; J Electroanal. Chem. 1979, 101, 351.

6. de Andrade, A. R.; Donate, P. M.; Alves. P. P. D.; Fidellis. H. V.; Boodts. J. F. C.; J. Electrochem. Soc. 1998, 145, 3839.

7. Shieh, D. T.; Hwang, B., J.; J. Electrochem. Soc. 1995, 142, 816-823.
8. Zanta, C.L.P.S; de Andrade, A. R.; Boodts, J. F. C.; Electrochim. Acta 1999, 44, 3333.

9. Sibille, S.; Moiroux, J.; Marot, J. C.; Deycard, S.; J. Electroanal. Chem. 1978, 88, 105 .

10. Fleury, M. B.; Letellier, S.; Dufrensne, J. C.; Moiroux, J.; $J$ Electroanal. Chem. 1978, 88, 123.

11. Motheo, A. J.; Gonzalez, E. R.; Tremiliosi-Filho, G.; Olivi, P.; Andrade, A. R.; Kokoh, B.; Léger, J-M.; Belgsir E. M.; Lamy, C.; J. Braz. Chem. Soc. 2000, 11, 16.

12. Trasatti. S. In Electrochemistry of Novel Materials, Frontiers of Electrochemistry; Lipkowsky, J.; Ross, P.N., ed., VCH: New York, 1994, ch. 5.

13. Kodinstev, I. M.; Trasatti, S.; Rubel, M.; Wieckowski, A.; Kaufner. N.; Langmuir 1992, 8, 283.

14. Streitweiser Jr., A.; Heathcock, C.; Introduction to Organic Chemistry; $3^{\text {rd }}$ ed., Maxwell Macmillan International Editions: New York; 1989.

15. Ristić, N. M.; Lačnjevac, C. M.; Jokić, A. M.; Tsiplakides, D.; Jaksić, M. M.; Russ. J. Electrochem. 1997, 33, 777.

Received: December 1, 2002 Published on the web: July 25, 2003

FAPESP helped in meeting the publication costs of this article. 